\title{
Ionization in the Plasma of a Copper Arc
}

\author{
Charles H. Corliss
}

(December 8, 1961)

\begin{abstract}
From the relative intensities of arc and spark lines observed in a d-c are in air between copper electrodes, the degree of ionization of eleven elements added to the copper has been determined. With the aid of Saha's ionization equation, the electron density in the arc was calculated to be $2.4 \times 10^{14} \mathrm{~cm}^{-3}$. Partition functions for atoms and ions of 29 elements are newly calculated or estimated and a table of first ionization potentials and partition functions of atoms and ions for seventy elements is presented. The degree of ionization of seventy elements separately added to the arc is calculated. The electron density in the arc is confirmed by three independent spectroscopic and electrical determinations. The data developed in this paper will enable the calculation of relative transition probabilities from the intensities in the NBS Tables of Spectral-Line Intensities.
\end{abstract}

\section{Introduction}

It is possible to determine the relative transition probabilities for the lines of a particular spectrum emitted by a hot gas, from measurements of the relative intensities of those lines, provided that the excitation in the radiating gas can be described by Boltzmann's law. It is necessary to know only the temperature of the gas. If the relative transition probabilities for lines of both the first and second spectra of an element are to be determined on the same scale, the degree of ionization in the radiating gas must be found.

In this paper we shall investigate the ionization in the positive column or plasma of a $10 \mathrm{amp} \mathrm{d-c} \mathrm{arc} \mathrm{in}$ air between copper electrodes. This is the arc which served as the light source for obtaining the intensity values reported in the NBS Tables of Spectral-Line Intensities [1] ${ }^{1}$.

In that work, an element under investigation was mixed with pure copper powder in the atomic ratio of 1 to 1,000 . The mixtures were pressed into solid cylindrical pellets $1 / 4$ in. in diameter, $1 / 4 \mathrm{in}$. in length, and weighing about $1 \frac{1}{2} \mathrm{~g}$. The pellets were mounted as electrodes in water-cooled clamps and a direct current of 10 amp passed between them from a $220-\mathrm{v}$ line with a resistive ballast. A 3-mm gap between the electrodes was imaged entirely within the aperture of a stigmatic grating spectrograph by a lens at the slit. In this arrangement light from all parts of the arc stream contributed to the spectralline intensities. Although the temperature and electron density in the are stream are functions of the axial and radial positions, we deal here only with mean values which are inherently weighted according to the intensity distribution in the arc. The excitation in this light source has been shown in a previous paper [2] to follow Boltzmann's law.

\section{Relative Intensities of Arc and Spark Lines}

When the intensity ratio of lines from neutral atoms and ions of an element is known in such a light

\footnotetext{
1 Figures in brackets indicate the literature references at the end of this paper.
}

source, it is possible to calculate the relative particle density of atoms and ions for that element, if the absolute transition probabilities or absolute $g f$-values for those lines are available. Designating quantities associated with a neutral atom and its spectrum by the superscript ${ }^{\circ}$ we can write the Einstein-Boltzmann equation for the intensity of a line of that spectrum in the form

$$
I^{\circ}=\frac{N^{\circ}}{u^{\circ}} h \nu^{\circ} g^{\circ} A^{\circ} e^{-\frac{E^{\circ}}{k T}}
$$

In this equation $N^{\circ}$ is the particle density of neutral atoms, $u^{\circ}$ is the partition function for the atom which expresses the distribution of neutral atoms over their possible energy states, $h \nu^{\circ}$ is the energy of a single photon, $g^{\circ}$ is the statistical weight of the upper state, $A^{\circ}$ is Einstein's transition probability for the particular line, $E^{\circ}$ is the energy of the upper state, $k$ is Boltzmann's constant and $T$ is the temperature of the copper arc. If we write a similar equation, designating quantities associated with an ion and its spectrum by the superscript ${ }^{+}$, and take the ratio of the two equations, we obtain

$$
\frac{I^{\circ}}{I^{+}}=\frac{N^{\circ}}{N^{+}} \frac{u^{+}}{u^{\circ}} \frac{\nu^{\circ}}{\nu^{+}} \frac{g^{\circ} A^{\circ}}{g^{+} A^{+}} e^{+\frac{E^{+}-E^{\circ}}{k T}} .
$$

For convenience we make appropriate substitutions of $\lambda$ instead of $\nu$ and $g f$ instead of $g A$ and solve for $N^{+} / N^{\circ}$.

$$
\frac{N^{+}}{N^{\circ}}=\frac{\left(I \lambda^{3}\right)^{+}}{\left(I \lambda^{3}\right)^{\circ}} \frac{u^{+}}{u^{\circ}} \frac{(g f)^{\circ}}{(g f)^{+}} e^{+\frac{E^{+}-E^{\circ}}{k T}} .
$$

For computation we take common logarithms and insert a numerical value for Boltzmann's constant.

$$
\begin{aligned}
\log \frac{N^{+}}{N^{\circ}}=\log \frac{\left(I \lambda^{3}\right)^{+}}{\left(I \lambda^{3}\right)^{\circ}}+\log \frac{u^{+}}{u^{\circ}}+\log \frac{(g f)^{\circ}}{(g f)^{+}} & \\
& +\frac{625}{T}\left(E^{+}-E^{\circ}\right) .
\end{aligned}
$$

In (4), $E$ is in kilokaysers and $T$ is in ${ }^{\circ} \mathrm{K}$. 
Of the 70 elements in the NBS Tables of SpectralLine Intensities, there are, at present, only 11 for which all the quantities on the right side of eq (4) are known. The data used in obtaining the numerical solutions are given in table 1 . The 11 atoms and ions are listed in order of atomic number in column 1. The wavelengths and intensities for the first term of the right member of eq (4) are taken from the Tables of Spectral-Line Intensities and given in columns 2 and 3 . In most cases, the total intensity for a multiplet is used; and only the first 4 figures of the wavelength of the leading line in the multiplet are listed. When $f$-values were available for more than one multiplet, an attempt was made to select multiplets of moderately high intensity for each spectrum. In cases where a single line is used, the decimals are given also. For the second term we list in column 4 the partition functions calculated by Claas and given in tables 27 and 29 of his paper [3]. In column 5 are found the sums of the absolute $g f-$ values for the lines. With two exceptions, only theoretical $g i$-values or experimental relative values adjusted to a theoretical absolute scale are employed. This is done because of the scarcity of experimental absolute values, especially for second spectra. The value for $\mathrm{Cd} \mathrm{I}$, however, is a measurement in absorption by King and Stockbarger [4]. The value used for $\mathrm{Pb}$ II is Stephenson's measurement [5] for the corresponding transition in isoelectronic Tl $\mathrm{I}$. References to the origin of the absolute $g f$-values are given in column 6 .

The energy levels of the upper states given in column 7 are taken from the Tables of Spectral-Line Intensities and are given in units of kilokaysers $\left(1 \mathrm{kK}=1000 \mathrm{~cm}^{-1}\right)$. For multiplets, weighted mean values are given. These values are used in the last term of eq (4) along with the temperature of the copper are determined in a previous paper [2]. This temperature $\left(5,100{ }^{\circ} \mathrm{K}\right)$ was determined by comparing 31 sets of experimental relative transition probabilities with the corresponding spectral-line intensities measured in the copper arc and reported in the Tables of Spectral-Line Intensities. The log ratio $N^{+} / N^{\circ}$ calculated from the data in the table by means of eq (4) is given in column 8 and the percent ionization of the element in column 9 is simply

$$
\frac{100 N^{+}}{N^{\circ}+N^{+}}=\frac{100 N^{+} / N^{\circ}}{1+N^{+} / N^{\circ}}
$$

The principal source of error in these determinations of ionization lies in the absolute $g f$ values, which are uncertain by more than a factor of 2 . The intensities contribute an uncertainty of 20 percent, and the temperature of the copper arc contributes from 2 percent to 12 percent, depending on the value of $\left(E^{+}-E^{\circ}\right)$.

\section{The Ionization Equation}

The procedure used for the 11 elements discussed in the previous section cannot be employed for the
TABLE 1. Experimental determination of ionization for eleven elements in the copper arc

\begin{tabular}{|c|c|c|c|c|c|c|c|c|}
\hline $\begin{array}{l}\text { Atom or } \\
\text { ion }\end{array}$ & $\begin{array}{l}\text { Wave- } \\
\text { length }\end{array}$ & $\begin{array}{l}\text { Inten- } \\
\text { sity }\end{array}$ & $u$ & $g f$ & $\begin{array}{l}\text { Refer- } \\
\text { ence }\end{array}$ & $E$ & $\log \frac{N+}{N^{\circ}}$ & $\begin{array}{c}\text { Percent } \\
\text { ioniza- } \\
\text { tion }\end{array}$ \\
\hline $\begin{array}{l}\mathrm{Be}^{\circ} \\
\mathrm{Be}^{+}\end{array}$ & $\begin{array}{r}\text { A } \\
3321 \\
3130\end{array}$ & $\begin{array}{l}160 \\
800\end{array}$ & $\begin{array}{l}1.0 \\
2.0\end{array}$ & $\begin{array}{l}3.06 \\
1.50\end{array}$ & $\begin{array}{l}{[6]} \\
{[6]}\end{array}$ & $\begin{array}{c}k K \\
52.082 \\
31.932\end{array}$ & -1.236 & 5.5 \\
\hline $\begin{array}{l}\mathrm{Mg}^{\circ} \\
\mathrm{Mg}^{+}\end{array}$ & $\begin{array}{l}3838 \\
2795\end{array}$ & $\begin{array}{r}940 \\
1,600\end{array}$ & $\begin{array}{l}1.0 \\
2.0\end{array}$ & $\begin{array}{l}\text { 6. } 0 \\
1.80\end{array}$ & $\begin{array}{l}{[7]} \\
{[7]}\end{array}$ & $\begin{array}{l}47.957 \\
35.72\end{array}$ & -0.852 & 12 \\
\hline $\begin{array}{l}\mathrm{Ca}^{\circ} \\
\mathrm{Ca}^{+}\end{array}$ & $\begin{array}{l}4226.73 \\
3933\end{array}$ & $\begin{array}{l}1,100 \\
6,400\end{array}$ & $\begin{array}{l}1.2 \\
2.2\end{array}$ & $\begin{array}{l}1.46 \\
2.20\end{array}$ & $\begin{array}{l}{[8]} \\
{[9]}\end{array}$ & $\begin{array}{l}23.652 \\
25.3\end{array}$ & .957 & 90 \\
\hline $\begin{array}{l}\mathrm{Sc}^{\circ} \\
\mathrm{Se}^{+}\end{array}$ & $\begin{array}{l}5671 \\
3613\end{array}$ & $\begin{array}{r}598 \\
6,606\end{array}$ & $\begin{array}{l}12.1 \\
23.2\end{array}$ & 11. 6.9 & $\begin{array}{l}{[7]} \\
{[7]}\end{array}$ & $\begin{array}{l}29.16 \\
27.65\end{array}$ & .761 & 85 \\
\hline $\begin{array}{l}\mathrm{Ti}^{\circ} \\
\mathrm{Ti}^{+}\end{array}$ & $\begin{array}{l}4305 \\
3759\end{array}$ & $\begin{array}{r}1,636 \\
532\end{array}$ & $\begin{array}{l}30.4 \\
55.9\end{array}$ & $\begin{array}{l}7.4 \\
5 .\end{array}$ & $\begin{array}{l}{[7]} \\
{[7]}\end{array}$ & $\begin{array}{l}29.98 \\
31.36\end{array}$ & -.056 & 47 \\
\hline $\begin{array}{l}\mathrm{V}^{\circ} \\
\mathrm{V}^{+}\end{array}$ & $\begin{array}{l}4111 \\
3093\end{array}$ & $\begin{array}{l}2,760 \\
1,936\end{array}$ & $\begin{array}{l}48.8 \\
43.0\end{array}$ & $\begin{array}{r}7.3 \\
11.2\end{array}$ & {$[7]$} & $\begin{array}{l}26.59 \\
35.06\end{array}$ & .284 & 66 \\
\hline $\begin{array}{l}\mathrm{Zn}^{\circ} \\
\mathrm{Zn}^{+}\end{array}$ & $\begin{array}{l}4810 \\
2061\end{array}$ & $\begin{array}{l}280 \\
15.5\end{array}$ & $\begin{array}{l}1.0 \\
2.0\end{array}$ & $\begin{array}{l}1.0 \\
1.8\end{array}$ & $\begin{array}{r}{[7]} \\
{[10]}\end{array}$ & $\begin{array}{l}53.672 \\
48.62\end{array}$ & -2.931 & 0.12 \\
\hline $\begin{array}{l}\mathrm{Sr}^{\circ} \\
\mathrm{Sr}^{+}\end{array}$ & $\begin{array}{l}4607.33 \\
4077\end{array}$ & $\begin{array}{r}650 \\
7,800\end{array}$ & $\begin{array}{l}\text { 1. } 3 \\
\text { 2. } 2\end{array}$ & $\begin{array}{l}1.8 \\
1.87\end{array}$ & $\begin{array}{l}{[7]} \\
{[7]}\end{array}$ & $\begin{array}{l}21.698 \\
24.19\end{array}$ & 1. 564 & 97 \\
\hline $\begin{array}{l}\mathrm{Cd}^{\circ} \\
\mathrm{Cd}^{+}\end{array}$ & $\begin{array}{l}3261.06 \\
2265\end{array}$ & $\begin{array}{r}32 \\
170\end{array}$ & $\begin{array}{l}1.0 \\
2.0\end{array}$ & $\begin{array}{l}0.0022 \\
1.8\end{array}$ & $\begin{array}{r}{[4]} \\
{[10]}\end{array}$ & $\begin{array}{l}30.656 \\
45.01\end{array}$ & -0.608 & 20 \\
\hline $\begin{array}{l}\mathrm{Ba}^{\circ} \\
\mathrm{Ba}^{+}\end{array}$ & $\begin{array}{l}5535.48 \\
4554\end{array}$ & $\begin{array}{r}650 \\
8,500\end{array}$ & $\begin{array}{l}2.5 \\
4.3\end{array}$ & $\begin{array}{l}1.92 \\
2.0\end{array}$ & {$[7]$} & $\begin{array}{l}18.060 \\
21.65\end{array}$ & 1. 569 & 97 \\
\hline $\begin{array}{l}\mathrm{Pb}^{\circ} \\
\mathrm{Pb}^{+}\end{array}$ & $\begin{array}{l}2401.95 \\
2203.53\end{array}$ & $\begin{array}{r}36 \\
9\end{array}$ & $\begin{array}{l}1.6 \\
2.1\end{array}$ & $\begin{array}{r}0.064 \\
.604\end{array}$ & $\begin{array}{r}{[10]} \\
{[5]}\end{array}$ & $\begin{array}{l}49.440 \\
59.448\end{array}$ & -0.260 & 35 \\
\hline
\end{tabular}

determination of the degree of ionization of the remaining 59. For these latter elements, the equation of ionization first developed by Saha [11] will be used. This is an equation describing the equilibrium existing, in a hot gas, between the relative concentration of atoms and ions of any particular atomic species and the concentration of free electrons, as a function of the temperature of the gas and the ionization potential of the atom under study. For our purpose it is convenient to write it in the form

$$
\frac{N^{+}}{N^{\circ}} N_{e}=\frac{(2 \pi m k T)^{3 / 2}}{h^{3}} \frac{2 u^{+}}{u^{\circ}} e^{-\frac{V}{k T}}
$$

where $N_{e}$ is the electron density, $m$ is the mass of the electron, and $V$ is the ionization potential of the atom.

\subsection{Electron Density}

For the 11 elements treated in the previous section all quantities in eq (5) are known except $N_{e}$. The mean value of $N_{e}$ determined from the evaluation of these 11 cases can be used to calculate $N^{+} / N^{\circ}$ for other elements for which partition functions and ionization potentials are known or can be estimated.

For computation we write eq (5) in the form

$$
\log N_{e}=21.245-0.988 \mathrm{~V}-\log \frac{N^{+}}{N^{\circ}}-\log \frac{u^{\circ}}{u^{+}}
$$


in which $T$ is taken to be $5,100{ }^{\circ} \mathrm{K}$, and $V$ is in volts. The 11 values of $N_{e}$ are given in table 2. Logarithmic averaging is appropriate here because errors proportional to the magnitudes of the quantities are involved.

\begin{tabular}{|c|c|c|c|}
\hline Element & $V$ & $u^{\circ} / u^{+}$ & $\log N_{e}$ \\
\hline $\begin{array}{l}\mathrm{Be} \\
\mathrm{Mg} \\
\mathrm{Ca} \\
\mathrm{Sc} \\
\mathrm{Ti}\end{array}$ & $\begin{array}{l}9.320 \\
7.644 \\
6.111 \\
6.54 \\
6.82\end{array}$ & $\begin{array}{r}0.500 \\
.500 \\
.545 \\
.522 \\
.544\end{array}$ & $\begin{array}{l}13.574 \\
14.846 \\
14.514 \\
14.306 \\
14.825\end{array}$ \\
\hline $\begin{array}{l}\mathrm{V} \\
\mathrm{Zn} \\
\mathrm{Sr} \\
\mathrm{Cd} \\
\mathrm{Ba}\end{array}$ & $\begin{array}{l}6.74 \\
9.391 \\
5.692 \\
8.991 \\
5.210\end{array}$ & $\begin{array}{r}1.135 \\
0.500 \\
.591 \\
.500 \\
.582\end{array}$ & $\begin{array}{l}\text { 14. } 246 \\
15.199 \\
14.285 \\
13.271 \\
14.764\end{array}$ \\
\hline $\mathrm{Pb}$ & 7.415 & .762 & 14. 297 \\
\hline \multicolumn{3}{|c|}{ A verage } & $14.375 \pm 0.413$ \\
\hline
\end{tabular}

The average value of electron density determined from the values in table 2 is $2.4 \times 10^{14}$ electrons $/ \mathrm{cm}^{3}$. This corresponds to an electron pressure of 170 dynes $/ \mathrm{cm}^{2}$ or $1.7 \times 10^{-4} \mathrm{~atm}$ at $5,100{ }^{\circ} \mathrm{K}$. The average deviation in $\log N_{e}$, given in table 2 , corresponds to a range of $N_{e}$ from 0.9 to $6 \times 10^{14} \mathrm{~cm}^{-3}$.

This large uncertainty originates in the uncertainty of the absolute values of $g f$. Consequently, it appears that the degree of ionization of the 11 elements listed in table 1 would be more accurately determined by recalculating $N^{+} / N^{\circ}$ from eq (6), using the mean value of $N_{e}$ obtained in table 2 . We will adopt this procedure and calculate the degree of ionization for all 70 elements. Rewriting eq (6) and substituting the mean value of $\log N_{e}$, we have

$$
\log \frac{N^{+}}{N^{\circ}}=6.870-0.988 \mathrm{~V}-\log \frac{u^{\circ}}{u^{+}} .
$$

The straight line in figure 1 is a plot of this equation. The points represent the directly determined experimental values from table 1 . The slope of the line is fixed by the temperature $\left(5,100{ }^{\circ} \mathrm{K}\right)$ determined in a previous paper [2] on the assumption of a Boltzmann distribution of energy. The location of the points with respect to this slope indicates that this temperature is appropriate to the calculation of ionization as well as excitation.

\subsection{Ionization Potentials and Partition Functions}

For accurate solutions of eq (7) we need good values of the ionization potentials and the partition functions. Ionization potentials listed in table 3 , column 3 are taken from volume III, table 34 of C. E. Moore's Atomic Energy Levels [12] with the exception of those for the rare earths and the more recent values for Ge [13], Hf [14], Os [15], and $\operatorname{Ir}$ [16]. For the rare earths, fairly good spectroscopic values are available for Sm [17], Eu [18], Gd [19], Yb [14], and $\mathrm{Lu}[20]$. The ionization potentials of the remaining rare earths are unknown, but as a group

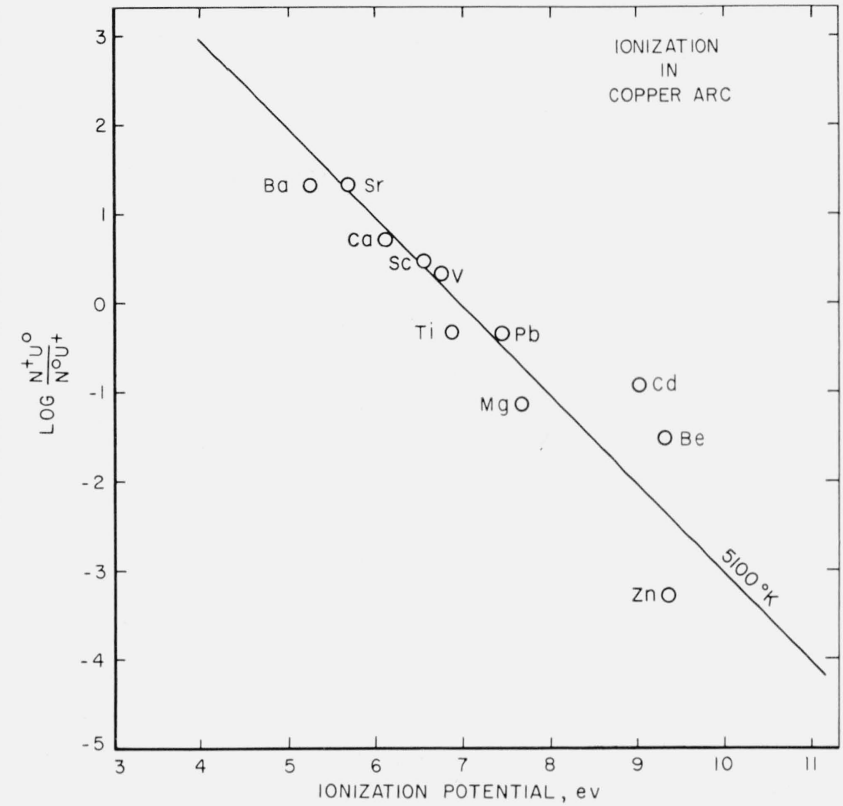

Figure 1. Degree of ionization in a copper arc in air.

The points are the experimentally determined values for eleven elements. The straight line represents Saha's ionization equation for a temperature of $5,100^{\circ} \mathrm{K}$ and an electron density of $2.4 \times 10^{14} \mathrm{~cm}^{-3}$.

these elements are remarkably uniform in their ease of ionization. The values given in parentheses are estimates based in some cases on adjusted nonspectroscopic values [21], [22]. They are likely to be not more than 10 percent from the true value.

The partition functions at $5,100{ }^{\circ} \mathrm{K}$ for the 41 elements Li through Ge, Rb through Mo, Pd through $\mathrm{Sn}$, Cs through La, and $\mathrm{Hg}$ through $\mathrm{Bi}$ in columns 4 and 5 of table 3 are taken from Claas [3]. Partition functions for 18 additional elements for which knowledge of the spectral terms is reasonably complete were calculated from the equation

$$
\mu=\sum_{n} g_{n} e^{-\frac{E n}{k T}}=\sum_{n} g_{n} 10^{-0.1225 E n}
$$

for all levels up to $14 \mathrm{kK}$. Above that value the Boltzmann factor is less than 2 percent. The partition functions for the 11 remaining elements could not be accurately determined because knowledge of the spectral terms is incomplete or wholly lacking. Estimated or assumed values, based partly on spectral structures predicted by Klinkenberg [23], and partly on comparison of the character of the observed spectrum with that of similar analysed spectra are given in parentheses.

The method given above for calculating partition functions for well-analysed spectra gives values in agreement to about 5 percent with those calculated by Claas. The assumed values (in parentheses) probably differ from the true values by less than a factor of 2 . The more reliable values and estimates suggest that for most of the rare earths the value of $u^{\circ} / u^{+}$lies between 0.4 and 0.8 ; accordingly, a value of 0.6 has been assumed for the inadequately analysed rare earths. This may be accurate to 50 percent. 
TABLE 3. Ionization potentials and partition functions for seventy elements

\begin{tabular}{|c|c|c|c|c|c|c|}
\hline 7 & Element & $V$ & $u^{\circ}$ & $u^{+}$ & $u^{\circ} / u^{+}$ & $\log u^{\circ} / u^{+}$ \\
\hline $\begin{array}{r}3 \\
4 \\
5 \\
6 \\
11\end{array}$ & $\begin{array}{c}\mathrm{Li} \\
\mathrm{Be} \\
\mathrm{B} \\
\mathrm{C} \\
\mathrm{Na}\end{array}$ & $\begin{array}{r}5.390 \\
9.320 \\
8.296 \\
11.256 \\
5.138\end{array}$ & $\begin{array}{l}2.1 \\
1.0 \\
6.0 \\
9.3 \\
2.1\end{array}$ & $\begin{array}{l}1.0 \\
2.0 \\
1.0 \\
6.0 \\
1.0\end{array}$ & $\begin{array}{l}2.1 \\
0.50 \\
6.0 \\
1.55 \\
2.1\end{array}$ & $\begin{array}{r}0.322 \\
-.301 \\
.778 \\
.190 \\
.322\end{array}$ \\
\hline $\begin{array}{l}12 \\
13 \\
14 \\
15 \\
19\end{array}$ & $\begin{array}{c}\mathrm{Mg} \\
\mathrm{Al} \\
\mathrm{Si} \\
\mathrm{P} \\
\mathrm{K}\end{array}$ & $\begin{array}{r}7.644 \\
5.984 \\
8.149 \\
10.484 \\
4.339\end{array}$ & $\begin{array}{l}1.0 \\
5.9 \\
9.5 \\
4.5 \\
2.2\end{array}$ & $\begin{array}{l}2.0 \\
1.0 \\
5.7 \\
8.2 \\
1.0\end{array}$ & $\begin{array}{l}0.50 \\
5.9 \\
1.67 \\
0.55 \\
2.2\end{array}$ & $\begin{array}{r}-.301 \\
.771 \\
.223 \\
-.260 \\
.342\end{array}$ \\
\hline $\begin{array}{l}20 \\
21 \\
22 \\
23 \\
24\end{array}$ & $\begin{array}{l}\mathrm{Ca} \\
\mathrm{Sc} \\
\mathrm{Ti} \\
\mathrm{V} \\
\mathrm{Cr}\end{array}$ & $\begin{array}{l}6.111 \\
6.54 \\
6.82 \\
6.74 \\
6.764\end{array}$ & $\begin{array}{r}1.2 \\
12.1 \\
30.4 \\
48.8 \\
10.6\end{array}$ & $\begin{array}{r}2.2 \\
23.2 \\
55.9 \\
43.0 \\
7.3\end{array}$ & $\begin{array}{l}0.55 \\
.522 \\
.544 \\
1.135 \\
1.45\end{array}$ & $\begin{array}{r}-.260 \\
-.282 \\
-.264 \\
.055 \\
.161\end{array}$ \\
\hline $\begin{array}{l}25 \\
26 \\
27 \\
28 \\
29\end{array}$ & $\begin{array}{l}\mathrm{Mn} \\
\mathrm{Fe} \\
\mathrm{Co} \\
\mathrm{Ni} \\
\mathrm{Cu}\end{array}$ & $\begin{array}{l}7.432 \\
7.87 \\
7.86 \\
7.633 \\
7.724\end{array}$ & $\begin{array}{r}6.5 \\
28.5 \\
33.1 \\
30.6 \\
2.4\end{array}$ & $\begin{array}{r}7.8 \\
43.6 \\
30.0 \\
11.0 \\
1.0\end{array}$ & $\begin{array}{l}0.83 \\
0.654 \\
1.103 \\
2.78 \\
2.4\end{array}$ & $\begin{array}{r}-.081 \\
-.184 \\
.042 \\
.444 \\
.380\end{array}$ \\
\hline $\begin{array}{l}30 \\
31 \\
32 \\
33 \\
34\end{array}$ & $\begin{array}{l}\mathrm{Zn} \\
\mathrm{Ga} \\
\mathrm{Ge} \\
\mathrm{As} \\
\mathrm{Se}\end{array}$ & $\begin{array}{l}9.391 \\
6.00 \\
7.899 \\
9.81 \\
9.75\end{array}$ & $\begin{array}{l}1.0 \\
5.2 \\
7.7 \\
4.6 \\
7.5\end{array}$ & $\begin{array}{l}2.0 \\
1.0 \\
4.4 \\
6.0 \\
4.2\end{array}$ & $\begin{array}{l}0.50 \\
5.2 \\
1.75 \\
0.77 \\
1.8\end{array}$ & $\begin{array}{r}-.301 \\
.716 \\
.243 \\
-.114 \\
. .255\end{array}$ \\
\hline $\begin{array}{l}37 \\
38 \\
39 \\
40 \\
41\end{array}$ & $\begin{array}{l}\mathrm{Rb} \\
\mathrm{Sr} \\
\mathrm{Y} \\
\mathrm{Zr} \\
\mathrm{Nb}\end{array}$ & $\begin{array}{l}4.176 \\
5.692 \\
6.38 \\
6.84 \\
6.88\end{array}$ & $\begin{array}{r}2.3 \\
1.3 \\
12.1 \\
35.3 \\
25.4\end{array}$ & $\begin{array}{r}1.0 \\
2.2 \\
16.2 \\
46.6 \\
23.2\end{array}$ & $\begin{array}{c}2.3 \\
0.59 \\
.75 \\
.758 \\
1.095\end{array}$ & $\begin{array}{r}.362 \\
-.229 \\
-.125 \\
-.120 \\
.039\end{array}$ \\
\hline $\begin{array}{l}42 \\
44 \\
45 \\
46 \\
47\end{array}$ & $\begin{array}{l}\mathrm{Mo} \\
\mathrm{Ru} \\
\mathrm{Rh} \\
\mathrm{Pd} \\
\mathrm{Ag}\end{array}$ & $\begin{array}{l}7.10 \\
7.364 \\
7.46 \\
8.33 \\
7.574\end{array}$ & $\begin{array}{r}8.7 \\
33.6 \\
26.2 \\
3.1 \\
2.0\end{array}$ & $\begin{array}{r}7.5 \\
23.3 \\
15.0 \\
7.5 \\
1.0\end{array}$ & $\begin{array}{l}1.16 \\
1.44 \\
1.75 \\
0.41 \\
2.0\end{array}$ & $\begin{array}{r}.064 \\
.158 \\
.243 \\
-.387 \\
.301\end{array}$ \\
\hline $\begin{array}{l}48 \\
49 \\
50 \\
51 \\
52\end{array}$ & $\begin{array}{l}\mathrm{Cd} \\
\mathrm{In} \\
\mathrm{Sn} \\
\mathrm{Sb} \\
\mathrm{Te}\end{array}$ & $\begin{array}{l}8.991 \\
5.785 \\
7.342 \\
8.639 \\
9.01\end{array}$ & $\begin{array}{l}\text { 1. } 0 \\
4.2 \\
5.3 \\
\text { 4. } 74 \\
6.30\end{array}$ & $\begin{array}{l}2.0 \\
1.0 \\
3.2 \\
3.43 \\
4.40\end{array}$ & $\begin{array}{l}0.50 \\
4.2 \\
1.66 \\
1.38 \\
1.43\end{array}$ & $\begin{array}{r}-.301 \\
.623 \\
.220 \\
.140 \\
.155\end{array}$ \\
\hline $\begin{array}{l}55 \\
56 \\
57 \\
58 \\
59\end{array}$ & $\begin{array}{l}\mathrm{Cs} \\
\mathrm{Ba} \\
\mathrm{La} \\
\mathrm{Ce} \\
\mathrm{Pr}\end{array}$ & $\begin{array}{c}3.893 \\
5.210 \\
5.61 \\
(5.6) \\
(5.5)\end{array}$ & $\begin{array}{r}2.5 \\
2.5 \\
20.2 \\
(110) \\
(50)\end{array}$ & $\begin{array}{c}1.0 \\
4.3 \\
30.2 \\
190 \\
(86)\end{array}$ & $\begin{array}{l}2.5 \\
0.58 \\
.67 \\
(.6) \\
(.6)\end{array}$ & $\begin{array}{r}.398 \\
-.237 \\
-.174 \\
-.22 \\
-.22\end{array}$ \\
\hline $\begin{array}{l}60 \\
62 \\
63 \\
64 \\
65\end{array}$ & $\begin{array}{l}\mathrm{Nd} \\
\mathrm{Sm} \\
\mathrm{Eu} \\
\mathrm{Gd} \\
\mathrm{Tb}\end{array}$ & $\begin{array}{l}(5.5) \\
5.6 \\
5.67 \\
6.16 \\
(6)\end{array}$ & $\begin{array}{c}(50) \\
(35) \\
9.2 \\
51 \\
(50)\end{array}$ & $\begin{array}{l}(86) \\
(57) \\
15.7 \\
78 \\
(80)\end{array}$ & $\begin{array}{l}(.6) \\
(.6) \\
.59 \\
.65 \\
(.6)\end{array}$ & $\begin{array}{l}-.22 \\
-.22 \\
-.229 \\
-.187 \\
-.22\end{array}$ \\
\hline $\begin{array}{l}66 \\
67 \\
68 \\
69 \\
70\end{array}$ & $\begin{array}{l}\text { Dy } \\
\mathrm{Ho} \\
\mathrm{Er} \\
\mathrm{Tm} \\
\mathrm{Yb}\end{array}$ & $\begin{array}{l}(6) \\
(6) \\
(6) \\
(6) \\
6.2\end{array}$ & $\begin{array}{l}(36) \\
(36) \\
(50) \\
(10) \\
1.00\end{array}$ & $\begin{array}{l}(60) \\
(60) \\
(80) \\
(17) \\
2.00\end{array}$ & $\begin{array}{l}(.6) \\
(.6) \\
(.6) \\
(.6) \\
.50\end{array}$ & $\begin{array}{l}-.22 \\
-.22 \\
-.22 \\
-.22 \\
-.301\end{array}$ \\
\hline $\begin{array}{l}71 \\
72 \\
73 \\
74 \\
75\end{array}$ & $\begin{array}{l}\text { Lu } \\
\text { Hf } \\
\text { Ta } \\
\text { W } \\
\text { Re }\end{array}$ & $\begin{array}{l}6.15 \\
6.8 \\
7.88 \\
7.98 \\
7.87\end{array}$ & $\begin{array}{r}8.52 \\
13.9 \\
16.4 \\
11.9 \\
6.7\end{array}$ & $\begin{array}{r}1.39 \\
12.3 \\
22.1 \\
12.8 \\
7.0\end{array}$ & $\begin{array}{r}6.13 \\
1.13 \\
0.74 \\
.93 \\
.96\end{array}$ & $\begin{array}{r}.788 \\
.053 \\
-.131 \\
-.032 \\
-.018\end{array}$ \\
\hline $\begin{array}{l}76 \\
77 \\
78 \\
79 \\
80\end{array}$ & $\begin{array}{l}\mathrm{Os} \\
\mathrm{Ir} \\
\mathrm{Pt} \\
\mathrm{Au} \\
\mathrm{Hg}\end{array}$ & $\begin{array}{c}8.5 \\
9.1 \\
9.0 \\
9.22 \\
10.43\end{array}$ & $\begin{array}{c}19.0 \\
20.9 \\
19.8 \\
2.45 \\
1.0\end{array}$ & $\begin{array}{c}17.6 \\
(14) \\
9.65 \\
1.10 \\
2.0\end{array}$ & $\begin{array}{c}1.08 \\
(1.5) \\
2.05 \\
2.23 \\
0.50\end{array}$ & $\begin{array}{c}.033 \\
.18 \\
.312 \\
.348 \\
-.301\end{array}$ \\
\hline $\begin{array}{l}81 \\
82 \\
83 \\
90 \\
92\end{array}$ & $\begin{array}{l}\mathrm{Tl} \\
\mathrm{Pb} \\
\mathrm{Bi} \\
\mathrm{Th} \\
\mathrm{U}\end{array}$ & $\begin{array}{l}6.106 \\
7.415 \\
7.287 \\
(6) \\
(6)\end{array}$ & $\begin{array}{r}2.5 \\
1.6 \\
4.3 \\
19.0 \\
(54)\end{array}$ & $\begin{array}{c}1.0 \\
2.1 \\
1.1 \\
34.3 \\
(80)\end{array}$ & $\begin{array}{l}2.5 \\
0.76 \\
3.9 \\
0.554 \\
(.67)\end{array}$ & $\begin{array}{r}.398 \\
-.119 \\
-.591 \\
-.256 \\
-.17\end{array}$ \\
\hline
\end{tabular}

\subsection{Degree of Ionization for 70 Elements}

Using the ionization potentials and the ratios of the partition functions from table 3 , we have evaluated eq (7) for each of the 70 elements added to the copper arc. The results are given in table 4 . Values in this table are to be preferred to the 11
TABLE 4. Degree of ionization for seventy elements

\begin{tabular}{|c|c|c|c|c|c|}
\hline Z & Element & $\log \mathrm{N}^{+} / \mathrm{N}^{\circ}$ & $\mathrm{N}^{+} / \mathrm{N}^{\circ}$ & $\begin{array}{c}\text { Percent } \\
\text { ions }\end{array}$ & $\begin{array}{l}\text { Percent } \\
\text { atoms }\end{array}$ \\
\hline $\begin{array}{r}3 \\
4 \\
5 \\
6 \\
11\end{array}$ & $\begin{array}{c}\mathrm{Li} \\
\mathrm{Be} \\
\mathrm{B} \\
\mathrm{C} \\
\mathrm{Na}\end{array}$ & $\begin{array}{r}1.223 \\
-2.037 \\
-2.104 \\
-4.441 \\
1.472\end{array}$ & $\begin{array}{c}16.7 \\
0.0092 \\
.0079 \\
.000036 \\
29.6\end{array}$ & $\begin{array}{c}94.4 \\
0.91 \\
.78 \\
.0036 \\
96.7\end{array}$ & $\begin{array}{c}5.65 \\
99 \\
99 \\
100 \\
3.26\end{array}$ \\
\hline $\begin{array}{l}12 \\
13 \\
14 \\
15 \\
19\end{array}$ & $\begin{array}{l}\mathrm{Mg} \\
\mathrm{Al} \\
\mathrm{Si} \\
\mathrm{P} \\
\mathrm{K}\end{array}$ & $\begin{array}{r}-0.381 \\
-187 \\
-1.404 \\
-3.228 \\
2.241\end{array}$ & $\begin{array}{c}0.42 \\
1.54 \\
0.039 \\
174^{.00059}\end{array}$ & $\begin{array}{l}29.4 \\
61 \\
3.8 \\
0.059 \\
99.4\end{array}$ & $\begin{array}{l}71 \\
39.4 \\
96 \\
100 \\
0.571\end{array}$ \\
\hline $\begin{array}{l}20 \\
21 \\
22 \\
23 \\
24\end{array}$ & $\begin{array}{l}\mathrm{Ca} \\
\mathrm{Sc} \\
\mathrm{Ti} \\
\mathrm{V} \\
\mathrm{Cr}\end{array}$ & $\begin{array}{r}1.092 \\
0.692 \\
.394 \\
.155 \\
.026\end{array}$ & $\begin{array}{c}12.4 \\
4.9 \\
2.48 \\
1.43 \\
1.06\end{array}$ & $\begin{array}{l}92.5 \\
83 \\
71 \\
59 \\
51.5\end{array}$ & $\begin{array}{r}7.5 \\
16.9 \\
28.8 \\
41 \\
49.5\end{array}$ \\
\hline $\begin{array}{l}25 \\
26 \\
27 \\
28 \\
29\end{array}$ & $\begin{array}{l}\mathrm{Mn} \\
\mathrm{Fe} \\
\mathrm{Co} \\
\mathrm{Ni} \\
\mathrm{Cu}\end{array}$ & $\begin{array}{l}-.392 \\
-.726 \\
-.942 \\
-1.115 \\
-1.141\end{array}$ & $\begin{array}{l}0.406 \\
.188 \\
.114 \\
.077 \\
.0723\end{array}$ & $\begin{array}{c}28.9 \\
15.8 \\
10.3 \\
7.1 \\
6.74\end{array}$ & $\begin{array}{l}71 \\
84 \\
90 \\
93 \\
93\end{array}$ \\
\hline $\begin{array}{l}30 \\
31 \\
32 \\
33 \\
34\end{array}$ & $\begin{array}{l}\mathrm{Zn} \\
\mathrm{Ga} \\
\mathrm{Ge} \\
\mathrm{As} \\
\mathrm{Se}\end{array}$ & $\begin{array}{l}-2.107 \\
0.226 \\
-1.177 \\
-2.706 \\
-3.015\end{array}$ & $\begin{array}{l}.0078 \\
1.68 \\
0.066 \\
.00197 \\
.00097\end{array}$ & $\begin{array}{l}0.776 \\
62.7 \\
6.24 \\
0.197 \\
.097\end{array}$ & $\begin{array}{l}99.2 \\
37.3 \\
93.8 \\
99.8 \\
99.9\end{array}$ \\
\hline $\begin{array}{l}37 \\
38 \\
39 \\
40 \\
41\end{array}$ & $\begin{array}{l}\mathrm{Rb} \\
\mathrm{Sr} \\
\mathrm{Y} \\
\mathrm{Zr} \\
\mathrm{Nb}\end{array}$ & $\begin{array}{r}2.382 \\
1.475 \\
0.695 \\
.230 \\
.031\end{array}$ & $\begin{array}{c}241 \\
29.8 \\
5.0 \\
1.70 \\
1.07\end{array}$ & $\begin{array}{l}99.6 \\
97 \\
83 \\
63 \\
52\end{array}$ & $\begin{array}{l}0.413 \\
3.24 \\
16.8 \\
37 \\
48\end{array}$ \\
\hline $\begin{array}{l}42 \\
44 \\
45 \\
46 \\
47\end{array}$ & $\begin{array}{l}\mathrm{Mo} \\
\mathrm{Ru} \\
\mathrm{Rh} \\
\mathrm{Pd} \\
\mathrm{Ag}\end{array}$ & $\begin{array}{l}-.204 \\
-.564 \\
-.743 \\
-.973 \\
-.914\end{array}$ & $\begin{array}{l}0.62 \\
.273 \\
.181 \\
.106 \\
.122\end{array}$ & $\begin{array}{r}38 \\
21.4 \\
15.3 \\
9.6 \\
10.9\end{array}$ & $\begin{array}{l}62 \\
79 \\
85 \\
90 \\
89.1\end{array}$ \\
\hline $\begin{array}{l}48 \\
49 \\
50 \\
51 \\
52\end{array}$ & $\begin{array}{l}\mathrm{Cd} \\
\mathrm{In} \\
\mathrm{Sn} \\
\mathrm{Sb} \\
\mathrm{Te}\end{array}$ & $\begin{array}{r}-1.712 \\
0.531 \\
-.604 \\
-1.805 \\
-2.185\end{array}$ & $\begin{array}{l}.0194 \\
3.40 \\
0.249 \\
.0157 \\
.0065\end{array}$ & $\begin{array}{c}1.90 \\
77.3 \\
19.9 \\
1.55 \\
0.65\end{array}$ & $\begin{array}{l}98.1 \\
22.7 \\
80.1 \\
98.4 \\
99\end{array}$ \\
\hline $\begin{array}{l}55 \\
56 \\
57 \\
58 \\
59\end{array}$ & $\begin{array}{l}\mathrm{Cs} \\
\mathrm{Ba} \\
\mathrm{La} \\
\mathrm{Ce} \\
\mathrm{Pr}\end{array}$ & $\begin{array}{l}2.626 \\
1.960 \\
1.504 \\
1.56 \\
1.69\end{array}$ & $\begin{array}{l}423 \\
91.2 \\
31.9 \\
36 \\
49\end{array}$ & $\begin{array}{l}99.8 \\
98.9 \\
97 \\
97 \\
98\end{array}$ & $\begin{array}{l}0.236 \\
\text { 1. } 08 \\
3.0 \\
2.8 \\
2.0\end{array}$ \\
\hline $\begin{array}{l}60 \\
62 \\
63 \\
64 \\
65\end{array}$ & $\begin{array}{l}\mathrm{Nd} \\
\mathrm{Sm} \\
\mathrm{Eu} \\
\mathrm{Gd} \\
\mathrm{Tb}\end{array}$ & $\begin{array}{l}1.66 \\
1.59 \\
1.499 \\
0.967 \\
1.09\end{array}$ & $\begin{array}{c}45 \\
39 \\
31.6 \\
9.3 \\
12 .\end{array}$ & $\begin{array}{l}98 \\
98 \\
96.9 \\
90.3 \\
92\end{array}$ & $\begin{array}{l}2.2 \\
2.5 \\
3.1 \\
9.7 \\
8\end{array}$ \\
\hline $\begin{array}{l}66 \\
67 \\
68 \\
69 \\
70\end{array}$ & $\begin{array}{l}\mathrm{Dy} \\
\mathrm{Ho} \\
\mathrm{Er} \\
\mathrm{Tm} \\
\mathrm{Yb}\end{array}$ & $\begin{array}{l}1.09 \\
1.09 \\
1.09 \\
1.09 \\
1.07\end{array}$ & $\begin{array}{l}12 \\
12 \\
12 \\
12 \\
11.8\end{array}$ & $\begin{array}{l}92 \\
92 \\
92 \\
92 \\
92\end{array}$ & $\begin{array}{l}8 \\
8 \\
8 \\
8 \\
7.8\end{array}$ \\
\hline $\begin{array}{l}71 \\
72 \\
73 \\
74 \\
75\end{array}$ & $\begin{array}{l}\mathrm{Lu} \\
\mathrm{Hf} \\
\mathrm{Ta} \\
\mathrm{W} \\
\mathrm{Re}\end{array}$ & $\begin{array}{r}0.002 \\
. .117 \\
-.789 \\
-.978 \\
-.892\end{array}$ & $\begin{array}{l}1.00 \\
1.31 \\
0.163 \\
.105 \\
.128\end{array}$ & \begin{tabular}{r}
\multicolumn{1}{c}{50.1} \\
57 \\
14.0 \\
9.5 \\
11.4
\end{tabular} & $\begin{array}{l}49.9 \\
43 \\
86 \\
90 \\
89\end{array}$ \\
\hline $\begin{array}{l}76 \\
77 \\
78 \\
79 \\
80\end{array}$ & $\begin{array}{l}\mathrm{Os} \\
\mathrm{Ir} \\
\mathrm{Pt} \\
\mathrm{Au} \\
\mathrm{Hg}\end{array}$ & $\begin{array}{l}-1.56 \\
-2.31 \\
-2.34 \\
-2.588 \\
-3.129\end{array}$ & $\begin{array}{l}.027 \\
.0049 \\
.0046 \\
.00258 \\
.00074\end{array}$ & $\begin{array}{l}2.7 \\
0.49 \\
.45 \\
.257 \\
.074\end{array}$ & $\begin{array}{l}97 \\
99 \\
99 \\
99.7 \\
99.9\end{array}$ \\
\hline $\begin{array}{l}81 \\
82 \\
83 \\
90 \\
92\end{array}$ & $\begin{array}{c}\mathrm{Tl} \\
\mathrm{Pb} \\
\mathrm{Bi} \\
\mathrm{Th} \\
\mathrm{U}\end{array}$ & \begin{tabular}{c}
0.439 \\
-.337 \\
\hdashline .921 \\
1.13 \\
1.04
\end{tabular} & $\begin{array}{c}2.75 \\
0.46 \\
.120 \\
13.5 \\
11\end{array}$ & $\begin{array}{l}73.3 \\
31.5 \\
10.71 \\
93 \\
92\end{array}$ & $\begin{array}{c}26.7 \\
68.5 \\
89.3 \\
7 \\
8\end{array}$ \\
\hline
\end{tabular}

individually determined values in table 1 . It is interesting to note in table 4 the periodicities of $N^{+} / N^{\circ}$ versus atomic number. This ratio varies more smoothly than the well known variation of the ionization potential with atomic number. 
At this point we may remark that for every 1,000 copper atoms in the copper arc stream, 67 electrons are contributed from copper ions. Even in the case of the most highly ionized added element not more than one electron can be contributed for every 1,000 atoms of copper. It is clear, then, that the added. elements cannot affect the electron density in the arc.

It should also be pointed out that the degree of double ionization in the arc is negligible in its effect on the ratio of atoms to ions. Of the elements added. to the copper, the one which may be expected to yield the largest number of doubly charged ions is barium. An evaluation of eq (7) for the ratio $\mathrm{Ba}^{++} / \mathrm{Ba}^{+}$shows that the proportion of barium which will be doubly ionized is only 0.02 percent.

\section{Independent Estimates of Electron Density}

To confirm the value of electron density determined in the foregoing section, we have estimated $N_{e}$ by three other methods, two of which do not involve spectroscopic observations.

\subsection{Relative Intensities of Copper and Oxygen Lines}

In the spectrum of the copper are in air, several lines of $\mathrm{O} \mathrm{I}$ are observed in the infrared. By comparing the relative intensities of these lines with those of $\mathrm{Cu}$ I by the method given in section 2 for arc and spark lines, we may derive the relative particle density of copper and oxygen atoms. If we know the composition of air at $5,100{ }^{\circ} \mathrm{K}$, we know the particle density of oxygen in the plasma and can calculate that of copper.

TABLE 5. Determination of relative particle density of oxygen and copper atoms

\begin{tabular}{|c|c|c|c|c|c|c|c|}
\hline Spectrum & $\begin{array}{l}\text { Wave- } \\
\text { length }\end{array}$ & $\begin{array}{l}\text { Inten- } \\
\text { sity }\end{array}$ & $u^{\circ}$ & $g f$ & Ref & $E$ & $\log \frac{N_{\mathrm{O}}^{\circ}}{N_{\mathrm{C} u}^{\circ}}$ \\
\hline $\begin{array}{l}\text { O I } \\
\text { Cu I }\end{array}$ & $\begin{array}{c}A \\
7774 \\
8408.15\end{array}$ & $\begin{array}{l}68 \\
4.5\end{array}$ & $\begin{array}{l}8.9 \\
2.3\end{array}$ & $\begin{array}{l}5.2 \\
0.007\end{array}$ & $\begin{array}{l}{[10]} \\
{[10]}\end{array}$ & $\begin{array}{l}k K \\
86.6 \\
55.0\end{array}$ & 2. 660 \\
\hline
\end{tabular}

The pertinent data for the lines of oxygen and copper are given in table 5, which is similar in presentation to table 1. Evaluating the analog of eq (4) for $N_{\mathrm{Cu}}^{\circ} / N_{\mathrm{o}}^{\circ}$, we find that there are about 457 oxygen atoms for every copper atom in the arc. According to Hilsenrath et al. [24], the atomic oxygen content of air at $5,100{ }^{\circ} \mathrm{K}$ is 30 mole percent so that there are 1,500 particles of air for every atom of copper. If we divide the particle density of air at atmospheric pressure and $5,100{ }^{\circ} \mathrm{K}\left(1.44 \times 10^{18} \mathrm{~cm}^{-3}\right)$ by 1,500 , we find that the particle density of copper atoms is $9.6 \times 10^{14} \mathrm{~cm}^{-3}$. Now if in eq (6) we were to let $N_{\mathrm{Cu}}^{+}=N_{e}$ and $N_{\mathrm{Cu}}^{\circ}=9.6 \times 10^{14}$, introduce the ionization potential and partition functions for copper and solve for $N_{e}$, we would find $N_{e}=1.3 \times 10^{14}$ $\mathrm{cm}^{-3}$.

However, it may be that not all of the electrons come from the ionization of copper. According to Gilmore's tables of the equilibrium composition of air [25], the electron concentration in air at atmospheric pressure and $5,100{ }^{\circ} \mathrm{K}$ is 0.007 mole percent or $1.0 \times 10^{14} \mathrm{~cm}^{-3}$. This represents the difference between the concentrations of the positive ions of $\mathrm{NO}$ and the negative ions of $\mathrm{O}$. No account is taken of the possible formation of $\mathrm{NO}_{2}^{-}$. The electron concentration is strongly dependent on the ionization potential for NO. Hilsenrath's tables show a nearly negligible electron concentration because he uses an older value of $9.4 \mathrm{v}$, but Gilmore uses a more recent value of $9.25 \mathrm{v}$.

To calculate the electron density resulting from the ionization equilibrium of both copper and $\mathrm{NO}$ in the arc we write the equilibrium constants for the ionization of copper and of nitric oxide.

$$
\begin{aligned}
& \frac{N_{\mathrm{Cu}}^{+} N_{e}}{N_{\mathrm{Cu}}^{\circ}}=K_{\mathrm{Cu}} ; \\
& \frac{N_{\mathrm{NO}}^{+} N_{e}}{N_{\mathrm{NO}}^{\circ}}=K_{\mathrm{NO}} .
\end{aligned}
$$

Furthermore we can write

$$
N_{e}=N_{\mathrm{Cu}}^{+}+N_{\mathrm{NO}}^{+}
$$

since other charged particles are in negligible concentration. Now substituting from (9a) and (9b) in (10) we have

$$
N_{e}=K_{\mathrm{Cu}} \frac{N_{\mathrm{Cu}}^{\circ}}{N_{e}}+K_{\mathrm{NO}} \frac{N_{\mathrm{NO}}^{\circ}}{N_{e}} .
$$

Multiplying through by $N_{e}$ we obtain

$$
\left(N_{e}\right)^{2}=K_{\mathrm{Cu}} N_{\mathrm{Cu}}^{\circ}+K_{\mathrm{NO}} N_{\mathrm{NO}}^{\circ} .
$$

The equilibrium constant for copper we obtain from Saha's equation, eq (5). (Note that this does not involve a knowledge of $N_{e}$.) We have just calculated the density of copper atoms from the relative intensities of copper and oxygen lines. The data for NO are obtained from Gilmore's tables. The last factor will not be affected by a change of $N_{e}$ because of the very small degree of ionization of NO. Evaluating (12) we find

and

$$
N_{e}^{2}=1.6 \times 10^{28}+1.2 \times 10^{28}=2.8 \times 10^{28}
$$

$$
N_{e}=1.7 \times 10^{14} \mathrm{~cm}^{-3} .
$$

This means that the total electron density reported in section 3.1 may consist of two approximately equal components, one arising from the ionization of copper atoms, the other from the equilibrium composition of air.

Bearing in mind the uncertainties in the absolute $g f$-values for copper and oxygen, the value of $N_{e}$ determined by this method is in tolerable agreement with the mean value of $2.4 \times 10^{14} \mathrm{~cm}^{-3}$ for the total concentration of electrons obtained in section 3.1 from the relative intensities of arc and spark lines. In fact, within the uncertainties mentioned above, the agreement provides a quantitative experimental 
demonstration of the validity of Saha's ionization equation, in application to our arc.

\subsection{Ratio of Current Density to Electron Velocity}

In this section we attempt to confirm the spectroscopically determined electron density by using electrical and geometrical observations of the copper arc.

The current density in the positive column of the arc was measured by forming a magnified image of the are in which instantaneous comparisons of the diameter were made against a centimeter scale. With a $3.0-\mathrm{mm}$ gap and a current of $9.8 \mathrm{amp}$, the diameter of the column midway between the electrodes was $2.7 \mathrm{~mm}$, corresponding to an average current density of $170 \mathrm{amp} / \mathrm{cm}^{2}$.

The axial field of an arc is composed of three parts: A very strong field very close to the anode, a weak field over most of the space between the electrodes, and a strong field very close to the cathode. The thickness of the anode and cathode fields is independent of the total gap so that changes in the total arc voltage with gap length reflect only changes in the voltage drop and length of the positive column. The axial field in the column can be determined from the slope of a plot of total arc voltage versus gap length. Twenty observations of our arc at gaps from 1 to $7 \mathrm{~mm}$ showed an increase of voltage from 23 to $41 \mathrm{v}$ in a strictly linear fashion. This corresponds to a field of $30 \mathrm{v} / \mathrm{cm}$ in the plasma.

With the aid of the measurements reported above and some rather dubious assumptions about the behavior of electrons, we can obtain an independent determination of the electron density.

\section{a. Macroscopic Point of View}

The density of any electric current is equal to the product of the electronic charge, the density of electrons in the current, and the average velocity of the electrons in the direction of current flow. Algebraically stated,

$$
j=e N_{e} v .
$$

Good measurements of the drift velocities of electrons in air at $273{ }^{\circ} \mathrm{K}$ have been made by Nielson and Bradbury [26]. They present their data as a function of $E / p$ in $\mathrm{v} / \mathrm{cm} / \mathrm{mm} \mathrm{Hg}$. Comparison of the high-temperature experiment with that of Nielson and Bradbury should be made at constant density, so we define an effective pressure

$$
P_{0}=P(273 / T)=760 \times 273 / 5,100=40.7 \mathrm{~mm} \mathrm{Hg}
$$

corresponding to the density of our arc plasma. Now our value of $E / p_{0}$ is $30 / 40.7=0.74 \mathrm{v} / \mathrm{cm} / \mathrm{mm} \mathrm{Hg}$. The drift velocity from the data of Nielson and Bradbury at this ratio of $E / p_{0}$ and $T=273{ }^{\circ} \mathrm{K}$ is $1.03 \times 10^{6} \mathrm{~cm} / \mathrm{sec}$. This velocity may be affected slightly by the different composition of air at $5,100^{\circ} \mathrm{K}$.

The electron velocity further depends on temperature through the velocity dependence on cross sec- tions. Because of poor information available on scattering cross sections, we can only make a crude guess as to how $v$ depends on $T$. On the basis of simple kinetic theory arguments, Loeb [27] suggests dependence on $T^{\frac{1}{2}}$. On this assumption we find at $5,100{ }^{\circ} \mathrm{K}$ that

$$
v=1.03 \times 10^{6}(5,100 / 273)^{\frac{1}{2}}=4.46 \times 10^{6} \mathrm{~cm} / \mathrm{sec} .
$$

Solving eq (13), we find that

$$
N_{e}=170 / 1.6 \times 10^{-19} \times 4.46 \times 10^{6}=2.4 \times 10^{14} \mathrm{~cm}^{-3},
$$

which is the same as the spectroscopic value.

\section{b. Microscopic Point of View}

In the paper in which he originally applied the term plasma to a neutral region of ionized gas [28], Langmuir gave an expression for the random current density passing through a plane arbitrarily oriented in the plasma:

$$
j=e N_{e}\left(\frac{k T}{2 \pi m}\right)^{\frac{1}{2}}=2.5 \times 10^{-14} N_{e} T^{\frac{1}{2}} .
$$

The derivation, based on a Maxwell-Boltzmann distribution, is given by Langmuir and Compton [29].

Consider the electrons passing through such a plane erected perpendicular to the axis of the arc column at its positive terminus, close to the beginning of the anode drop. The electrons which pass through the plane into the anode drop will be collected at the anode and measured in our ammeter. Those passing in the opposite direction will not reach an electrode and will not affect the measured arc current. If this in fact happens, we can calculate $N_{e}$ from eq (10) by letting $j=170 \mathrm{amp} / \mathrm{cm}^{2}$ and $T=5,100{ }^{\circ} \mathrm{K}$.

$$
N_{e}=4.0 \times 10^{13} j T^{-1 / 2}=1.0 \times 10^{14} \mathrm{~cm}^{-3} .
$$

This is within the uncertainty of the spectroscopic value.

\section{Discussion}

Unfortunately it is not possible to prove that the necessary local thermodynamic equilibrium obtains in this arc, justifying the use of the Saha equation to determine the ionization balance. As has been pointed out in this and the preceding paper [2], the population of excited states in the are follows a Boltzmann distribution at a temperature which gives a very reasonable value of the electron density when the Saha equation is assumed. One might be tempted to avoid the assumption of LTE in the analysis of the data and apply a more generalized equation for the ionization balance, such as that developed by Dewan [30]. If one applies, blindly, the Dewan equations to the metallic constituents of the arc alone, then the relatively high degree of ionization and low electron density would suggest the applicability of the coronal formula [31]. The coronal formula can be fitted to the data of table I, with about 
the same residual scatter as when the Saha equation is used, but only if a temperature of $7,500{ }^{\circ} \mathrm{K}$ is assumed. Not only is this temperature in conflict with that determined from the excitation distribution but the coronal formula also ignores the effect of the predominate abundance of neutral atoms and molecules of air at atmospheric pressure in the arc. Although the processes of excitation and ionization in such an arc involving neutral particles primarily are so complex that not enough of the rate coefficients are known to permit a non-LTE treatment, it does not seem implausible that these three-body reactions do bring the plasma into LTE and justify the use of the Saha equation.

\section{Conclusion}

The relative numbers of ions and atoms in an arc plasma can be determined if intensities, wavelengths, partition functions, absolute $g f$-values and energy levels associated with the ions and atoms and the temperature of the plasma are known. Enough of these quantities are known for 11 of 70 elements excited in our arc to permit these relative numbers to be found. A solution of Saha's equation for each of these cases gives an average value of electron density of $2.4 \times 10^{14} \mathrm{~cm}^{-3}$ in our arc. With the aid of partition functions, some of which are here calculated for the first time, the degree of ionization for each of 70 elements in our copper arc is calculated.

The electron density determined in this manner is, within expected uncertainties, in agreement with the density determined by independent spectroscopic and electrical measurements. The agreement demonstrates the applicability of Saha's ionization equation to our arc. It should be pointed out that the degree of ionization of our 70 elements could have been determined empirically from the data of figure 1 without any assumptions regarding equations or mechanisms of ionization.

The information on the degree of ionization reported in this paper enables us to calculate, on a single scale, relative transition probabilities for all the classified lines of both first and second spectra which appear in the NBS Tables of Spectral-Line Intensities. If proper normalization factors can be found, this scale will be put on an absolute basis. Such a calibration will be discussed in a forthcoming paper. At the conclusion of these studies, we expect to publish transition probabilities and $g f$-values for the 25,000 classified lines in the NBS Tables, if possible, on an absolute scale.
The author acknowledges the help of Earl Beaty in interpreting data on electron velocities, of Joseph Hilsenrath concerning the data on the equilibrium composition of air, and of R. H. Garstang with regard to theoretical aspects of ionization and $f$-values. I also thank L. M. Branscomb for the many lively discussions he engendered.

\section{References}

[1] W. F. Meggers, C. H. Corliss, and B. F. Scribner, Tables of spectral-line intensities, NBS Mono. 32 (1961) (U.S. Government Printing Office, Washington, D.C.).

[2] C. H. Corliss, J. Research NBS 66A, 5 (1962).

[3] W. J. Claas, Recherches Astronomiques de l'Observatoire d'Utrecht, Vol. XII, Pt. 1 (1951).

[4] R. B. King and D. C. Stockbarger, Astrophys. J. 91, 488 (1940).

[5] G. Stephenson, Proc. Phys. Soc. (London) 64A, 458 (1951).

[6] J. L. Greenstein and E. Tandberg-Hanssen, Astrophys. J. 119, 113 (1954).

[7] C. W. Allen, Astrophysical Quantities, Univ. London (The Athlone Press, 1955).

[8] E. Trefftz, Zeits. f. Astrophysik 29, 287 (1951).

[9] E. Trefftz and L. Biermann, Zeits. f. Astrophysik 30, 275 (1952).

[10] R. H. Garstang (unpublished).

[11] M. N. Saha, Phil. Mag. 40, 472 (1920)

[12] C. E. Moore, Atomic energy levels, NBS Circ. 467, Vol. I (1949), Vol. II (1952), Vol. III (1958) (U.S. Government Printing Office, Washington, D.C.)

[13] K. L. Andrew and K. W. Meissner, J. Opt. Soc. Am. 49, 146 (1959).

[14] W. F. Meggers (unpublished)

[15] T. A. M. van Kleef and P. F. A. Klinkenberg, Physica 27, 83 (1961).

[16] T. A. M. van Kleef, Physica 23, 843 (1957).

[17] W. Albertson, Phys. Rev. 52, 644 (1937).

[18] H. N. Russell and A. S. King, Astrophys. J. 90, 155 (1939).

[19] H. N. Russell, J. Opt. Soc. Am. 40, 550 (1950).

[20] P. F. A. Klinkenberg, Physica 21, 53 (1955).

[21] L. Rolla and G. Piccardi, Phil. Mag. 7, 286 (1929).

[22] I. N. Bakulina and N. I. Ionov., Soviet Phys. J. E. T. P. 9, 709 (1959); N. I. Ionov and M. A. Mittsev., ibid. 11, $972(1960)$ and 13, 518 (1961).

[23] P. F. A. Klinkenberg, Physica 13, 1 (1947).

[24] J. Hilsenrath, M. Klein, and H. Woolley, Tables of thermodynamic properties of air including dissociation and ionization from $1500{ }^{\circ} \mathrm{K}$ to $15000^{\circ} \mathrm{K}$, AEDCTR-59-20, Arnold Engineering Development Center, Air Research and Development Command. U. S. A. F. (1959) (Dept. of Commerce, OTS PB161311).

[25] F. R. Gilmore, Equilibrium composition and thermodynamic properties of air to $24000^{\circ} \mathrm{K}, \mathrm{RM}-1543$ (1955) Rand Corp., Santa Monica, Calif.

[26] R. A. Nielson and N. E. Bradbury, Phys. Rev. 51, 69 (1937).

[27] L. B. Loeb, Basic processes of gaseous eleetronics, Univ. Calif. Press (1955)

[28] I. Langmuir, Phys. Rev. 33, 954 (1929).

[29] I. Langmuir and K. T. Compton, Rev. Mod. Phys. 3, 220 (1931).

[30] E. M. Dewan, Phys. of Fluids 4, 759 (1961).

[31] G. Elwert, Z. Naturforsch. 7a, 432, 703 (1952). 